\title{
WHEN TO POSTPONE CATARACT SURGERY: TAKING IN CONSIDERATION PATIENTS' QUALITY OF LIFE
}

\author{
Jovanovic Milos, ${ }^{1,2}$ Glisic Selimir, ${ }^{2}$ Stankovic Zora, ${ }^{2}$ Dacic Krnjaja Bojana ${ }^{2}$ \\ ${ }^{1}$ Faculty of Medicine, University of Belgrade, Serbia \\ ${ }^{2}$ Clinic for eye diseases, Clinical Centre of Serbia, Serbia
}

Primljen/Received 02. 08. 2015. god.

Abstract: Purpose: Assessment of complication in surgery of complicated cataracts and option of postponement of surgery.

Setting: Clinic for eye diseases, Clinical Centre of Serbia

Methods: This was a retrospective observational case series.

Results: In 16 patients subjected to cataract surgery by method of phacoemulsification, three experienced complications during surgery. Two experienced rupture of posterior lens capsule and prolapse of the vitreous body, and one, expulsive hemorrhage. The visual acuity in all three patients was lesser than the preoperative visual acuity. In the second group of 16 patients, after having been acquainted with the survey, the cataract surgery was postponed and the patients were controlled after one year. The cataract progressed just partially in certain patients and all the patients were satisfied with the status of their vision and did not demand surgery.

CONCLUSIONS: Cataract surgery in complicated cases may be accompanied by complications with uncertain postoperative visual results. Therefore, in patients with complicated cataracts and relatively preserved visual acuity, it is necessary to be careful with proposing surgery and often obey their wish to postpone surgery. This should be done particularly with patients of advanced age, patients with poor general status of life and in monoculuses.

Key words: Complicated cataracts; phacoemulsification; surgical complications; postponement of surgery; ophthalmological control.

\section{INTRODUCTION}

One could say that presently cataract surgery has almost reached perfection. This applies not only to surgery (phacoemulsification), but also to postoperative
Prihvaćen/Accepted 09. 10. 2015. god.

functional restoration using implantation of various intraocular lenses (IOL) $(1,2)$. It is also necessary to emphasize that operative and postoperative complications are minimized. However, in spite of all this the operative and postoperative complications, although rare, can happen and lead to serious impairment of sight in the operated eye (3-10).

\section{DECISION ON CATARACT SURGERY IN SPECIAL CASES}

The possibility of the appearance of unforeseen complications during or after surgery is a reason for the surgeon to take extreme care in proposing and undertaking cataract surgery in certain specific cases. The patients know very little if anything about these complications. That is why the surgeon also needs to acquaint them before surgery with the possibility that the cataract surgery might not pass as well as they expect and tell them that sometimes vision can be poorer after surgery or may sometimes end in complete loss of vision. Only after detailed information should the patient make the final decision whether to undergo or postpone surgery and take regular ophthalmological controls. Particular attention needs to be paid with the following patients: 1. patients who lack an eye (anophthalmos), or cannot see with the eye for some other reason and a cataract is present in the sole remaining eye. It is necessary to consider well with such patients whether to operate or subject the patient to regular controls and monitor further progression of the cataract. The following patients fall under this category: a) still actively functional monoculuses with an incipient cataract in the sole eye and visual acuity greater than $0.8 \mathrm{~b}$ ) retired monoculus patients with a cataract and visual acuity greater than $0.3 \mathrm{c}$ ) monoculuses in advanced years and poor general state of health with visual acuity less than 0.3 
but still sufficient to perform basic daily living requirements 2. patients with a cataract in both eyes and visual acuity in the better eye greater than 0.6 but with poor general state of health 3. patients with complicated cataracts with a greater percentage of operative and postoperative complications and visual acuity in the better eye greater than 0.3 .

We should explain to such patients that there is a greater possibility of complications with cataract surgery and the visual acuity might be worse after the surgery. Simply put, they may have something to lose. They should be suggested to avoid surgery and to report regularly for ophthalmological follow-ups, and only when the visual acuity is so weakened and represents serious daily disturbance, to undergo cataract surgery. They simply have nothing to lose then.

\section{MATERIAL AND METHODS}

The present study was approved by the ethical committee of the University Hospital Belgrade and informed consent was obtained from each patient after full explanation of the procedural nature.

Thirty-two patients with an increased possibility of development of complications during cataract surgery were examined at the Clinic for eye diseases, Clinical Centre of Serbia. All the patients underwent previous detailed ophthalmological and internal-medical examination and were provided with detailed explanation of the nature of cataract surgery and the possible benefit as well as possible operative and postoperative complications. After that the patients were given the questionnaire, which they read and answered the existing questions.

$$
\begin{aligned}
& \text { 1. How well do you see? } \\
& \text { a. well } \\
& \text { b. relatively well } \\
& \text { c. badly }
\end{aligned}
$$

2. How do you see in the distance?

a. well

b. recognition of image difficult

c. badly

3. Can you see to read? Do you see well enough to read?

a. yes, without correction

b. yes, when using glasses for correction

c. cannot see even with correction

4. How well do you orient yourself in space?

a. well

b. with difficulty

c. badly

\section{Do you want to undergo surgery?}

a. no

b. if you advise

c. yes

6. Are you aware of the possibility of existence of operative and postoperative complications we have discussed that would lead to reduction of preoperative vision or complete loss of vision?
a. yes
b. yes, partially
c. no

7. Did you have a chance to talk to anyone whose operation did not end well?
a. yes
b. no

8. Do you wish to undergo surgery even after having been acquainted in detail with the nature of the operation and possible complications?

a. I do not want to

b. I will postpone the surgery for later

c. I do want to

Following this, 16 patients decide to undergo cataract surgery immediately and the other 16 were in favor of postponement of the surgery and accepted the regular ophthalmological monitoring.

The patients which opted for surgery had phacoemulsification and all the operations were made by an experienced phaco surgeon (MJ). The follow-up of the second group of patients who opted for postponed surgery was performed after half a year and after a year.

This paper presents the results of surgery in the first group of 16 operated patients and findings in the second group of 16 patients, with particular review of the state of the cataract, visual acuity and satisfaction of the patient with the current state of vision.

\section{RESULTS}

In the first group of 16 operated patients (Table 1) the operative course passed regularly with 13 patients, and in 10 patients the achieved postoperative visual acuity was normal 1.0, and in 3 patients below normal due to some other accompanying eye disease. However, complications occurred in 3 patients during the surgery, namely, rupture of the posterior lens capsule with vitreous body prolapse in 2 patients (patients under ordinal number 2 and 8), whereas in the third patient an expulsive hemorrhage occurred during the surgery (patient under ordinal number 16). The postoperative visual acuity in the first two patients was poorer with respect to the preoperative and in the third patient amaurosis occurred. 
Table 1. Patients with complicated shape cataract which underwent phacoemulsification

\begin{tabular}{|c|c|c|c|c|c|c|c|c|c|}
\hline Case & Sex & Age & Ophthalmic diagnosis & $\begin{array}{l}\text { Preop } \\
\text { VO e }\end{array}$ & $\begin{array}{l}\text { rative } \\
\text { d IOP }\end{array}$ & Surgeye & $\begin{array}{l}\text { Postop } \\
\text { VO e1 }\end{array}$ & $\begin{array}{l}\text { rative } \\
\text { d IOP }\end{array}$ & complications \\
\hline 1 & M & 74 & $\begin{array}{l}\text { OD: Cat sen incip. PEX } \\
\text { OS: Pseudophakia. PEX }\end{array}$ & $\begin{array}{l}0,4 \\
1,0\end{array}$ & $\begin{array}{l}16,0 \\
14,0\end{array}$ & OD & $\begin{array}{l}1,0 \\
1,0\end{array}$ & $\begin{array}{l}14,0 \\
14,0\end{array}$ & without \\
\hline 2 & $\mathrm{~F}$ & 81 & $\begin{array}{l}\text { OD: Cat sen incip. Myopia alta } \\
\text { OS: St. post rupturam bulbi }\end{array}$ & $\begin{array}{l}0,2 \\
\text { am }\end{array}$ & $\begin{array}{l}12,0 \\
17,0\end{array}$ & OD & $\begin{array}{c}1 / 60 \\
\text { am }\end{array}$ & $\begin{array}{l}11,0 \\
16.0\end{array}$ & $\begin{array}{l}\text { Ruptura caps } \\
\text { post. Prol CV }\end{array}$ \\
\hline 3 & M & 76 & $\begin{array}{l}\text { OD: Gl. absolutum } \\
\text { OS: Cat sen incip }\end{array}$ & $\begin{array}{l}\mathrm{am} \\
0,4\end{array}$ & $\begin{array}{l}13,0 \\
13,0\end{array}$ & OS & $\begin{array}{l}\text { am } \\
1,0\end{array}$ & $\begin{array}{l}13,0 \\
11,0\end{array}$ & without \\
\hline 4 & M & 82 & $\begin{array}{l}\text { OD: Cat sen incip } \\
\text { OS: Anophthalmus }\end{array}$ & $\begin{array}{c}0,3 \\
1\end{array}$ & $\begin{array}{c}14,0 \\
/\end{array}$ & OD & $\begin{array}{c}1,0 \\
/\end{array}$ & $\begin{array}{c}12,0 \\
1\end{array}$ & without \\
\hline 5 & $\mathrm{~F}$ & 74 & $\begin{array}{l}\text { OD: Cat complicata uveitica } \\
\text { OS: Pseudophakia. Kerat bullosa }\end{array}$ & $\begin{array}{l}3 / 60 \\
\mathrm{~L}+\mathrm{P}-\end{array}$ & $\begin{array}{l}14,0 \\
16,0\end{array}$ & OD & $\begin{array}{c}1,0 \\
\mathrm{~L}+\mathrm{P}-\end{array}$ & 11,0 & without \\
\hline 6 & $\mathrm{~F}$ & 74 & $\begin{array}{l}\text { OD: Cat sen incip. DCE - Fuchs } \\
\text { OS: Pseudophakia. Kerat bullosa }\end{array}$ & $\begin{array}{c}0,3 \\
\mathrm{~L}+\mathrm{P}+\end{array}$ & $\begin{array}{l}14,0 \\
18,0\end{array}$ & OD & $\begin{array}{c}1,0 \\
\mathrm{~L}+\mathrm{P}+\end{array}$ & $\begin{array}{l}12,0 \\
18,0\end{array}$ & without \\
\hline 7 & $\mathrm{~F}$ & 79 & $\begin{array}{l}\text { OD: Leucoma corn vasc post cs } \\
\text { OS: Cat sen incip }\end{array}$ & am & $\begin{array}{l}14,0 \\
14,0\end{array}$ & OS & $\begin{array}{l}\text { am } \\
1,0\end{array}$ & $\begin{array}{l}14.0 \\
12,0\end{array}$ & without \\
\hline 8 & M & 78 & $\begin{array}{l}\text { OD: Cat sen incip } \\
\text { OS: Cat sen incip }\end{array}$ & $\begin{array}{l}1,0 \\
0,7\end{array}$ & $\begin{array}{l}15,0 \\
15,0 \\
\end{array}$ & OS & $\begin{array}{c}1,0 \\
1 / 60 \\
\end{array}$ & $\begin{array}{l}15,0 \\
15,0 \\
\end{array}$ & $\begin{array}{l}\text { Ruptura caps } \\
\text { post. Prol CV }\end{array}$ \\
\hline 9 & $\mathrm{~F}$ & 63 & $\begin{array}{l}\text { OD: Cat complicata uveitica } \\
\text { OS: Gl absolutum }\end{array}$ & $\begin{array}{l}0,4 \\
\text { am }\end{array}$ & $\begin{array}{l}16,0 \\
30,0\end{array}$ & OD & $\begin{array}{l}1,0 \\
\mathrm{am}\end{array}$ & $\begin{array}{l}13,0 \\
30,0\end{array}$ & without \\
\hline 10 & $\mathrm{~F}$ & 64 & $\begin{array}{l}\text { OD: Myopia alta, Abl ret inop } \\
\text { OS: Myopia alta. Cat brun incip }\end{array}$ & $\begin{array}{l}\mathrm{am} \\
0,2\end{array}$ & $\begin{array}{l}10.0 \\
12,0\end{array}$ & OS & $\begin{array}{l}\mathrm{am} \\
0,6\end{array}$ & $\begin{array}{l}10,0 \\
11,0\end{array}$ & without \\
\hline 11 & $\mathrm{~F}$ & 64 & $\begin{array}{l}\text { OD: Myopia alta. Cat brun incip } \\
\text { OS: Myopia alta. Atrophio bulbi }\end{array}$ & $\begin{array}{l}0,3 \\
\mathrm{am}\end{array}$ & $\begin{array}{c}12,0 \\
/\end{array}$ & OD & $\begin{array}{l}1,0 \\
\text { am }\end{array}$ & $\begin{array}{c}11,0 \\
/\end{array}$ & without \\
\hline 12 & M & 86 & $\begin{array}{l}\text { OD: Cat sen brun. Gl simplex } \\
\text { OS: Gl absolutum }\end{array}$ & $\begin{array}{l}0,2 \\
\text { am }\end{array}$ & $\begin{array}{l}16,0 \\
25,0\end{array}$ & OD & $\begin{array}{l}0,7 \\
\text { am }\end{array}$ & $\begin{array}{l}13,0 \\
25,0\end{array}$ & without \\
\hline 13 & $\mathrm{~F}$ & 82 & $\begin{array}{l}\text { OD: Cat sen brun. Gl simplex } \\
\text { OS: Gl absolutum }\end{array}$ & $\begin{array}{l}0,2 \\
\text { am }\end{array}$ & $\begin{array}{l}18,0 \\
34,0\end{array}$ & OD & $\begin{array}{l}0,6 \\
\mathrm{am}\end{array}$ & $\begin{array}{l}16,0 \\
34,0\end{array}$ & without \\
\hline 14 & $\mathrm{~F}$ & 77 & $\begin{array}{l}\text { OD: Atrophio bulbi } \\
\text { OS: Cat sen incip }\end{array}$ & am & $\begin{array}{l}1 \\
14,0\end{array}$ & OS & $\begin{array}{l}\mathrm{am} \\
1,0\end{array}$ & $\begin{array}{c}1 \\
13,0\end{array}$ & without \\
\hline 15 & M & 82 & $\begin{array}{l}\text { OD: Gl absolutum. Cat compl } \\
\text { OS: Cat sen intum. Gl simplex }\end{array}$ & $\begin{array}{c}\text { am } \\
1 / 60\end{array}$ & $\begin{array}{l}36,0 \\
20,0\end{array}$ & OS & $\begin{array}{l}\mathrm{am} \\
\mathrm{am}\end{array}$ & $\begin{array}{l}36,0 \\
24,0\end{array}$ & $\begin{array}{c}\text { Haemorrhagi } \\
\text { expulsiva }\end{array}$ \\
\hline 16 & $\mathrm{~F}$ & 78 & $\begin{array}{l}\text { OD: Cat sen incip. PEX } \\
\text { OS: Cat sen incip. PEX }\end{array}$ & $\begin{array}{l}0,9 \\
0,5\end{array}$ & $\begin{array}{l}17,0 \\
16,0\end{array}$ & OS & $\begin{array}{l}0,9 \\
1,0\end{array}$ & $\begin{array}{l}17,0 \\
15,0\end{array}$ & without \\
\hline
\end{tabular}

$\mathrm{M}=$ male; $\mathrm{F}=$ female; $\mathrm{VO}=$ visual acuity; $\mathrm{IOP}=$ intraocular pressure; $\mathrm{OD}$ : right eye; OS: left eye; am = amaurosis; $\mathrm{CV}=$ vitreous; $\mathrm{PEX}=$ pseudoexfoliation syndrome; $\mathrm{DCE}=$ degeneratio corneae endoteliales; $\mathrm{L}+\mathrm{P}-=$ light perception without precise projection; $\mathrm{L}+\mathrm{P}+=$ light perception with precise projection

The second group of 16 patients opted after reading the questions and providing the respective answers in the survey not to undergo surgery (Table 2). At the control examination 6 months later only 3 patients (under numbers $7,11,13$ ) experienced poorer vision by just one line read on the Snellen chart and at the control 12 months later, whereas the visual acuity dropped by one more line on the Snellen chart in 10 patients. However, all of them retained their decision to have regular checkups and no surgery.

\section{DISCUSSION}

In the first group of 16 operated patients, with 13 the phacoemulsification passed without operative complications. In 10 out of these 13 operated patients the postoperative visual acuity was normal $(1.0 ; 6 / 6)$, whereas the postoperative visual acuity in 3 patients was somewhat below normal due to other associated ophthalmological diseases. In the patient under ordinal number 10 the visual acuity was 0.6 due to degenerative myopic changes in the posterior eye pole, and in the patient under ordinal number 12 and patient under ordinal number 13 the postoperative visual acuity was 0.7 and 0.6 respectively because of the change on the optic nerve papilla due to open-angle glaucoma.

It is particularly important to note that in 3 patients complications occurred during phacoemulsification, which resulted in decrease of vision with respect to the patients' vision prior to surgery. The patient under ordinal number 2 in the Table, aged 81 , had an early cataract and high myopia in the right eye with visual acuity of 0.2 . There was a former injury of the eyeball (rupture) which resulted in amaurosis. In other words, this was a monoculus patient. During the phacoemulsification surgery of the right eye the posterior capsule ruptured with a prolapse of the vitreous body. After the definite surgical care the visual acuity was signifi- 
Table 2. Patients with complicated shape cataract with delayed cataract surgery

\begin{tabular}{|c|c|c|c|c|c|c|c|c|c|c|}
\hline Case & Sex & Age & Ophthalmic diagnosis & $\begin{array}{r}\mathrm{Fi} \\
\text { exami } \\
\mathrm{VO}\end{array}$ & $\begin{array}{l}\text { st } \\
\text { lation } \\
\text { OP }\end{array}$ & $\begin{array}{c}\text { An eye } \\
\text { for } \\
\text { a surgery }\end{array}$ & $\begin{array}{l}\text { Aft } \\
\text { mo } \\
\text { TO }\end{array}$ & & $\begin{array}{l}\text { Afte } \\
\text { mor } \\
\text { VO }\end{array}$ & \\
\hline 1 & $\mathrm{~F}$ & 75 & $\begin{array}{l}\text { OD: Gl absolutum } \\
\text { OS: Cat complicata uveitica }\end{array}$ & $\begin{array}{c}\mathrm{Am} \\
3 / 60\end{array}$ & $\begin{array}{l}30,0 \\
16,0\end{array}$ & OS & $\begin{array}{l}\mathrm{Am} \\
3 / 60\end{array}$ & $\begin{array}{l}35,0 \\
16,0\end{array}$ & $\begin{array}{c}\mathrm{Am} \\
3 / 60\end{array}$ & $\begin{array}{l}35,0 \\
16,0\end{array}$ \\
\hline 2 & $\mathrm{~F}$ & 80 & $\begin{array}{l}\text { OD: Pseudophakia Kerat bull } \\
\text { OS: Cat sen incip. DCE - Fuchs }\end{array}$ & $\begin{array}{c}\mathrm{L}+\mathrm{P}- \\
0,5\end{array}$ & $\begin{array}{l}19,0 \\
13,0\end{array}$ & OS & $\begin{array}{c}\mathrm{L}+\mathrm{P}- \\
0,5\end{array}$ & $\begin{array}{l}19,0 \\
13,0\end{array}$ & $\begin{array}{c}\mathrm{Am} \\
0,4\end{array}$ & $\begin{array}{l}20,0 \\
12,0\end{array}$ \\
\hline 3 & M & 76 & $\begin{array}{l}\text { OD: Cat sen incip } \\
\text { OS: Cat sen incip }\end{array}$ & $\begin{array}{l}0,6 \\
1,0\end{array}$ & $\begin{array}{l}14,0 \\
14,0\end{array}$ & OD & $\begin{array}{l}0,6 \\
0,9\end{array}$ & $\begin{array}{l}14,0 \\
14,0\end{array}$ & $\begin{array}{l}0,5 \\
0,9\end{array}$ & $\begin{array}{l}15,0 \\
15,0\end{array}$ \\
\hline 4 & $\mathrm{~F}$ & 82 & $\begin{array}{l}\text { OD: Cat compl. Gl caps. PEX } \\
\text { OS: Gl absolutum }\end{array}$ & $\begin{array}{l}3 / 60 \\
\mathrm{Am}\end{array}$ & $\begin{array}{l}14,0 \\
32,0\end{array}$ & OD & $\begin{array}{l}3 / 60 \\
\mathrm{Am}\end{array}$ & $\begin{array}{l}14,0 \\
34,0\end{array}$ & $\begin{array}{c}3 / 60 \\
\mathrm{Am}\end{array}$ & $\begin{array}{l}13,0 \\
33,0\end{array}$ \\
\hline 5 & M & 72 & $\begin{array}{l}\text { OD: Cat sen incip. } \\
\text { OS: Anophthalmus. }\end{array}$ & $\begin{array}{c}0,6 \\
/\end{array}$ & $\begin{array}{c}12,0 \\
/\end{array}$ & OD & $\begin{array}{c}0,6 \\
/\end{array}$ & $\begin{array}{c}12,0 \\
/\end{array}$ & 0,5 & $\begin{array}{c}12,0 \\
/\end{array}$ \\
\hline 6 & M & 73 & $\begin{array}{l}\text { OD: Cat sen incip. AMD } \\
\text { OS: Pseudophakia. AMD }\end{array}$ & $\begin{array}{l}0,7 \\
0,2\end{array}$ & $\begin{array}{l}18,0 \\
12,0\end{array}$ & OD & $\begin{array}{l}0,6 \\
0,2\end{array}$ & $\begin{array}{l}17,0 \\
12,0\end{array}$ & $\begin{array}{l}0,5 \\
0,2\end{array}$ & $\begin{array}{l}17,0 \\
12,0\end{array}$ \\
\hline 7 & M & 81 & $\begin{array}{l}\text { OD: Cat sen incip. RD } \\
\text { OS: Pseudophakia, RD.Kerat bull }\end{array}$ & $\begin{array}{c}0,4 \\
\mathrm{~L}+\mathrm{P}+\end{array}$ & $\begin{array}{l}15,0 \\
17,0\end{array}$ & OD & $\begin{array}{c}0,3 \\
\mathrm{~L}+\mathrm{P}+\end{array}$ & $\begin{array}{l}15,0 \\
17,0\end{array}$ & $\begin{array}{c}0,3 \\
\mathrm{~L}+\mathrm{P}+\end{array}$ & $\begin{array}{l}15,0 \\
18,0\end{array}$ \\
\hline 8 & $\mathrm{~F}$ & 79 & $\begin{array}{l}\text { OD: St post rupturam bulbi } \\
\text { OS: Cat sen incip }\end{array}$ & $\begin{array}{c}\mathrm{Am} \\
0,5\end{array}$ & $\begin{array}{l}12,0 \\
15,0\end{array}$ & OS & $\begin{array}{c}\mathrm{Am} \\
0,5\end{array}$ & $\begin{array}{l}12,0 \\
15,0\end{array}$ & $\begin{array}{c}\mathrm{Am} \\
0,4\end{array}$ & $\begin{array}{l}12,0 \\
15,0\end{array}$ \\
\hline 9 & $\mathrm{~F}$ & 76 & $\begin{array}{l}\text { OD: Anophthalmus. } \\
\text { OS: Cat sen incip }\end{array}$ & ' & $\begin{array}{c}\prime \\
16,0\end{array}$ & OS & ' & $\begin{array}{c}/ \\
16,0\end{array}$ & $\begin{array}{l}\prime \\
0,4\end{array}$ & $\begin{array}{c}\prime \\
16,0\end{array}$ \\
\hline 10 & $\mathrm{~F}$ & 64 & $\begin{array}{l}\text { OD: Myopia alta. Abl ret inop } \\
\text { OS: Myopia alta. Cat compl. }\end{array}$ & $\begin{array}{c}\mathrm{Am} \\
0,5\end{array}$ & $\begin{array}{l}10,0 \\
14,0\end{array}$ & OS & $\begin{array}{c}\mathrm{Am} \\
0,5\end{array}$ & $\begin{array}{l}10,0 \\
15,0\end{array}$ & $\begin{array}{c}\mathrm{Am} \\
0,4\end{array}$ & $\begin{array}{l}10,0 \\
15,0\end{array}$ \\
\hline 11 & M & 64 & $\begin{array}{l}\text { OD: Pseudophakia } \\
\text { OS: Cat sen incip. PEX }\end{array}$ & $\begin{array}{l}1,0 \\
0,8\end{array}$ & $\begin{array}{l}15,0 \\
15,0\end{array}$ & OS & $\begin{array}{l}1,0 \\
0,7\end{array}$ & $\begin{array}{l}15,0 \\
14,0\end{array}$ & $\begin{array}{l}1,0 \\
0,7\end{array}$ & $\begin{array}{l}14,0 \\
14,0\end{array}$ \\
\hline 12 & $\mathrm{~F}$ & 63 & $\begin{array}{l}\text { OU: Cat sen brun. Gl caps. St } \\
\text { post YAG iridotomiam }\end{array}$ & $\begin{array}{l}0,4 \\
0,6\end{array}$ & $\begin{array}{l}17,0 \\
17,0\end{array}$ & OD & $\begin{array}{l}0,4 \\
0,6\end{array}$ & $\begin{array}{l}17,0 \\
17,0\end{array}$ & $\begin{array}{l}0,3 \\
0,5\end{array}$ & $\begin{array}{l}18,0 \\
18,0\end{array}$ \\
\hline 13 & M & 84 & $\begin{array}{l}\text { OD: Cat sen incip. Chor per acta } \\
\text { OS: Cat se incip }\end{array}$ & $\begin{array}{l}0,6 \\
1,0\end{array}$ & $\begin{array}{l}16,0 \\
16,0\end{array}$ & OD & $\begin{array}{l}0,6 \\
0,9\end{array}$ & $\begin{array}{l}18,0 \\
18,0\end{array}$ & $\begin{array}{l}0,5 \\
0,8\end{array}$ & $\begin{array}{l}17,0 \\
17,0\end{array}$ \\
\hline 14 & $\mathrm{~F}$ & 87 & $\begin{array}{l}\text { OD: Cat sen incip } \\
\text { OS: Pseudophakia. Kerat bull }\end{array}$ & $\begin{array}{c}0,6 \\
\mathrm{~L}+\mathrm{P}+\end{array}$ & $\begin{array}{l}13,0 \\
13,0\end{array}$ & OD & $\begin{array}{c}0,6 \\
\mathrm{~L}+\mathrm{P}+\end{array}$ & $\begin{array}{l}13,0 \\
13,0\end{array}$ & $\begin{array}{c}0,5 \\
\mathrm{~L}+\mathrm{P}+\end{array}$ & $\begin{array}{l}14,0 \\
14,0\end{array}$ \\
\hline 15 & $\mathrm{~F}$ & 78 & $\begin{array}{l}\text { OU: Cat sen incip. PEX. } \\
\text { Iridophacodonesis }\end{array}$ & $\begin{array}{l}0,8 \\
0,6\end{array}$ & $\begin{array}{l}15,0 \\
15,0\end{array}$ & OS & $\begin{array}{l}0,7 \\
0,6\end{array}$ & $\begin{array}{l}15,0 \\
15,0\end{array}$ & $\begin{array}{l}0,7 \\
0,5\end{array}$ & $\begin{array}{l}16,0 \\
16,0\end{array}$ \\
\hline 16 & M & 81 & $\begin{array}{l}\text { OU: Cat sen incip. PEX. } \\
\text { Iridophacodonesis }\end{array}$ & $\begin{array}{l}0,8 \\
0,6\end{array}$ & $\begin{array}{l}16,0 \\
16,0\end{array}$ & OS & $\begin{array}{l}0,7 \\
0,6\end{array}$ & $\begin{array}{l}16,0 \\
16,0\end{array}$ & $\begin{array}{l}0,7 \\
0,6\end{array}$ & $\begin{array}{l}16,0 \\
16,0\end{array}$ \\
\hline
\end{tabular}

$\mathrm{AMD}=$ age-related macular degeneration; $\mathrm{RD}=$ diabetic retinopathy

cantly lesser and equal to $1 / 60$. For the time being she uses glasses for correction. Patient under ordinal number 8 , aged 78 , had a very early cataract in both eyes, somewhat more progressed in the left eye, with visual acuity 1.0 in right and 0.7 in left eye. According to the anamnesis he also had a contusion injury of the left eye. After reading the questions from the survey he wanted to undergo surgery of the left eye, which was performed. During the phacoemulsification it proved that there was a dehiscention of the zonula in a part of circumference of the lens and prolapse of the vitreous body. The postoperative visual acuity was $1 / 60$. The intraocular lens was not implanted and the patient corrects the aphakia on the operated eye with contact lens and visual acuity is 1.0 . The patient under ordinal number 15 , aged 82 had the most difficult surgical complication. She had absolute glaucoma and amaurosis of the right eye and mature cataract and long-standing glaucoma with visual acuity of $1 / 60$ on the left eye. She was in a relatively poor general state of health with ar- terial hypertension and arteriosclerosis. During the phacoemulsification of the left eye expulsive hemorrhage occurred which resulted in development of amaurosis on that eye as well. The number of 3 patients with surgical complications in the group of 16 operated patients is $18.7 \%$, which is a high percentage, however, it is necessary to bear in mind that these were patients with cataract that was complicated for surgery.

The second group of 16 patients, after detailed ophthalmological examination, talked with the ophthalmologist and once acquainted with the questionnaire, refrained from cataract surgery with an agreement reached with their surgeon of the need of regular ophthalmological follow-up. The reason for refraining from surgery at that moment was a relatively good visual acuity in the eye affected by cataract that was supposed to be operated, which provided the patient a relatively good quality of life, accompanied by fear of surgical complications, and in some cases also a relatively poor general state of health in the advanced years of li- 
fe. Among these patients there were 2 with anophthalamus, 4 with amaurosis, 1 with a light perception without precise projection and 2 with light perception with precise projection in the other eye that was lost for sight and was not foreseen for surgery. This was due to various diseases: absolute glaucoma, keratopathy after cataract surgery in that eye, inoperative retinal detachment, injury. The patient aged 75 under ordinal number 1 had amaurosis in the right eye due to absolute glaucoma and complicated uveitic cataract in the left eye. In addition to this she was in a poor general state of health. Although having quite a low visual acuity of 3/60 for surgery in the left eye, she provided information that she manages quite well at home and in a familiar environment, and that is sufficient to her in this phase of life. She stated that she would undergo surgery only when her vision deteriorated further. The 80 year old patient under ordinal number 3 , the 80 year old patient under ordinal number 7 and the 87 year old patient under ordinal number 14 had visual acuity in the eye with a cataract that was supposed to be operated of $0.7,0.5$ and 0.6 respectively. However, in addition to the incipient cataract they also had Fuchs' corneal endothelial dystrophy. Furthermore, in the other eyes of these patients the cataract had already been operated by phacoemulsification and intraocular lens (pseudophakia) implanted, however, decompensation of the cornea took place and bullous keratopathy developed. Their fear of surgery was clear and so was their desire to postpone the operation of the remaining eye, as they stated that they are satisfied with the existing visual acuity and quality of life. The patient aged 82 under ordinal number 4 had visual acuity in the right eye for surgery of $3 / 60$ and amaurosis in the other eye. However, in addition to the complicated cataract in the eye foreseen for operation there was also capsular glaucoma and pseudoexfoliation; hence, due to the possibility of surgical complication the patient refrained from surgery at that moment. The patients under ordinal numbers 5 and 9 had only one eye and an incipient senile cataract in that eye with visual acuity of 0.6 and 0.5 . They refrained from surgery because they considered that the existing visual acuity provided them a relatively good quality of life and that they would not take the risk at this moment considering that they did only had one eye. A similar line of thinking was present in patients under ordinal numbers 8 and 10 with amaurosis in the right eye. The patient under ordinal number 6 is interesting. He previously underwent cataract surgery in the left eye, but the visual acuity remained unchanged compared to the visual acuity before surgery and was equal to 0.2 , and the reason for this was a progressed dry degeneration of the macula. There was senile cataract in the right eye in an incipient phase but also early degenera- tion of the macula. This was the reason for refraining from surgery at this moment. The 62 year old patient under ordinal number 12 had incipient senile cataract in both eyes but also capsular glaucoma with performed YAG laser iridotomy in both eyes, and an extremely shallow anterior chamber and posterior sinechia and visual acuity of 0.4 and 0.6 . She was satisfied with the existing visual acuity in both eyes, and in addition to this, with the presented possible surgical complications consented with the postponement of surgery at this moment. All the other patients in the table had incipient cataracts in both eyes, relatively preserved visual acuity in both eyes which ranged from 0.6 to 1.0 and pseudoexfoliation with more or less pronounced iridophacodonesis. They considered that the existing visual acuity fulfilled their daily needs and that they would not expose themselves at this moment to the risk of surgery.

All these patients underwent examination by the same surgeon after 6 months and after one year. The cataracts in the eyes that were considered for surgery progressed very slowly so that after 6 months there were only 5 patients with reduced visual acuity by one line on the Snellen charge, and after 12 months there were 9 patients with reduction of one line according to Snellen. Two patients under ordinal number 1 and 5 with least visual acuity and complicated cataract in one functional eye did not have further reduction of visual acuity during the period of one year.

One year after the initial consideration of the need for cataract surgery, all the patients were satisfied with their visual acuity and quality of life it had provided them, so that they refrained from surgery with the need of further regular ophthalmological follow ups.

\section{CONCLUSION}

Cataract surgery, although having reached high safety limits, can be accompanied in a certain percentage of cases with the appearance of complications which can result in poor postoperative vision in that eye. This should be borne in mind particularly in cases of cataracts with a higher risk of complications and in case of cataracts in monoculuses.

- In this category of patients, usually in advanced years and with other general illnesses, it is necessary to clarify additionally the increased possibility of complications, conduct the survey proposed in this work and perform surgery only if they consent.

- It is also necessary to bear in mind their relatively reduced general living needs during that period of life and also accept their satisfaction with somewhat reduced vision and quality of life. It is necessary just to control them regularly and subject them to cataract surgery when they are ready for it. 


\section{Conflict of interests}

All authors certify that they have NO affiliations with or involvement in any organization or entity with any financial interest (such as honoraria; educational grants; participation in speakers' bureaus; member- ship, employment, consultancies, stock ownership, or other equity interest; and expert testimony or patent-licensing arrangements), or non-financial interest (such as personal or professional relationships, affiliations, knowledge or beliefs) in the subject matter or materials discussed in this manuscript.

\title{
Sažetak
}

\section{DOGOVOR SA PACIJENTOM O ODLAGANJU OPERACIJE KATARAKTE U POSEBNIM SLUČAJEVIMA - KVALITET ŽIVOTA}

\author{
Jovanovic Milos, ${ }^{1,2}$ Glisic Selimir, ${ }^{2}$ Stankovic Zora, ${ }^{2}$ Dacic Krnjaja Bojana ${ }^{2}$ \\ ${ }^{1}$ Faculty of Medicine, University of Belgrade, Serbia \\ ${ }^{2}$ Clinic for eye diseases, Clinical Centre of Serbia, Serbia
}

UVOD: Procena nastanka komplikacija pri operacijama komplikovanih katarakti i mogućnosti odlaganja operacija.

METODE: Praćenje i analiza dve serije pacujenata sa komplikovanim kataraktama, jedne kod koje je izvršena operacija i druge bez operacije.

REZULTATI: Kod 16 pacijenata kod kojih je rađena operacija katarakte metodom fakoemulzifikacije kod tri je nastala komplikacija u toku operacije. Kod dva je došlo do rupture zadnje kapsule sočiva i prolapsa staklastog tela, a kod jednog do nastanka ekspulzivne hemoragije. Kod sva tri pacijenta postoperativna vidna oštrina je bila manja od preoperativne. Kod druge grupe od 16 pacijenata, posle upoznavanja sa anketom, operacija katarakte je bila odložena i na kontroli posle godinu

\section{REFERENCES}

1. Koch PS. Simplifying phacoemulsiphicationsSafe and efficient methods for cataract surgery. Fifth Edition SLACK Incorporated, Thorofare, $\mathrm{Nj}$. 1997: 103-29.

2. Fine H, Packer M, Hoffman R. Surgical techniques for small incision cataract surgery. In: Kohen T, Koch DD eds, Cataract and Refractive Surgery. Springer-Verlag, Berlin Heidelberg 2005: 19-36.

3. De Corten C, Faggioni R Spontaneus rupture of posterior capsule. J Cataract Refract Surg. 2008; 34(2): 179-80.

4. Pong JC, Lai JS. Managing the hard posterior polar cataract J Cataract Refract Surg. 2008; 34(4): 530-1.

5. Sharma TK, Nessim M, Kyprianou I, Kumar V, Shah P, O'Neil E. Vitreos loss during phacoemulsiphication in glauco- dana katarakta je samo delimično napredovala kod pojedinih pacijenata i svi pacijenti su bili zadovoljni svojim stanjem vida i nisu zahtevali operaciju.

ZAKLJUČAK: Operacija katakte kod komlikovanih slučajeva može biti praćena komplikacijama sa neizvesnim postoperativnim vidnim rezultatom. Zato kod pacijenata sa komplikovanim kataraktama i relativno očuvanom vidnom oštrinom, treba biti oprezan pri predlaganju operacije $\mathrm{i}$ često poslušati njihovu želju za odlaganjem operacije. To posebno treba činiti kod pacijenata u poznim godinama života, pacijenata sa lošim opštim životnim statusom i kod monokulusa.

Ključne reči: Komplikovana katarakta, fakoemulzifikacija, operativne komplikacije, odlaganje operacije, oftalmološka kontrola.

ma patients: long term intraocular pressure control. J Cataract Refract Surg. 2008; 34(5): 831-4.

6. Hill WE. Cataract surgical problem, J Cataract Refract Surg. 2007; 33: 185-91.

7. Walland MJ, Stevens JD, Steele AD. Repair of Descemet' membrane detachment after inraocular surgery. J Cataract Refract Surg. 1995; 21(3): 250-3.

8. Rho DS. Treatment of acute pseudophakic cystoid macular edema: diclofenac versus keterolac. J Cataract Refract Surg. 2003; 29(12): 2378-84.

9. Olson RJ. Reducing the risk of postoperative endophthalmitis. Surv Ophthalmol. 2004; 49 (Suppl 2): S55-61.

10. Ng JQ, Morlet N, Bremner AP, Bulsara MK, Morton AP, Semmens JP. Techniques to monitor for endophtalmitis and other cataract surgery complications. Ophthalmology. 2008; 115(1): 3-10.

\section{Correspondence to /Autor za korespondenciju}

Miloš Jovanović, MD, PhD

Belgrade

Serbia

milosjovanovic951@gmail.com 